\title{
Changes of the Surface Texture after Surface Treatment HS6-5-2-5 Steel
}

Ondřej Klanica ${ }^{1}$, Emil Svoboda ${ }^{1}, Z_{\text {Zdeněk Joska }}^{2}$

${ }^{1}$ Faculty of Military Technology, University of Defence Brno. Kounicova 65, 66210 Brno. Czech Republic. E-mail: ondrej.klanica@unob.cz,emil.svoboda@unob.cz

${ }^{2}$ Ministry of Defence - CIRC, Kounicova 44, 66210 Brno. E-mail: joska.zdenek@email.cz

Texture of the surface is very important in process reproduction of the components. Not only in engineering area, but also in other industrial sectors, the assessment of the surface texture ranks among basic techniques of the determining the surface properties of the component. Pretreatment of the surface can reduce running costs in the case of coating on the tools. The paper describes the changes of the surface textures of the HS6-5-2-5 steel CSN EN ISO 4957 with different technological treatments of the substrates, coating and subsequently polishing of the coating. Substrate was sandblasted (wet) and polished before coating. Coating nACo ${ }^{\circledR}$ was applied by PVD method and surface of the coating specimens was subsequently polished by $\mu$ Lap method. Surface textures together with properties of the coating are decisive factors for their lifetime and durability of the cutting tools. The qualitative assessment of the changes surface texture was carried out by the 3D topography measurement of the surface by using Talysurf CCI Lite. TalyMap software was used for evaluation of the changes surface texture. For evaluation of the surface were used parameters: Sa - arithmetic mean deviation of the surface [ $\mu \mathrm{m}]$, Sdq - root mean square slope of the surface $[-]$ and $R k$ - core roughness depth $[\mu \mathrm{m}]$. The results in the paper demonstrate positive effect of the polishing on texture coating on the tools.

Keywords: Surface textures, Coating, Parameters of the surface textures, Polishing, Sandblasting

\section{Acknowledgement}

The paper was prepared with the support of the Project for the Development of the Organization and by the Specific research project 2014 of the Department of Mechanical Engineering, UoD "Promoting Research, Science and Innovation in the Field of Engineering".

\section{References}

[1] JIANG, J., ARNELL, R. D., (2000): The effect of substrate surface roughness on the wear DLC coatings. Wear, vol. 239, 2000, pp. 1-9.

[2] HUANG, R., QI, Z., SUN, P., WANG, Z., WU, CH., (2011): Influence of the substrate roughness on structure and mechanical property of TiAlN coating by cathodic arc evaporation. Physics Procedia, vol. 18, 2011, pp. 160-167.

[3] SANTOS, S., SALES, W., SILVA, F., FRANCO, S., SILVA, M., (2004): Tribological characterisation of PVD coating for cutting tools. Surface and Coatings Technology, vol. 184, pp. 141-148.

[4] HANES, T., HVIZDOŠ, P., ŤAVOdOVÁ, M., KALINCOVÁ, D., HRICOVÁ, J., BEŇO, P., (2014):Coating surface measurement made on coining dies. Manufacturing Technology, vol. 14, 2014, pp: 309-317.

[5] KASINA, M., KAROL, V., (2014): Experimental verification of the relation between the surface roughness and type of use tool coating, Manufacturing Technology, vol. 12, 2014, pp. 27-30.

[6] ČSN EN ISO 4957, (2003): Oceli nástrojové. Česká technická norma, Český normalizační institut. Praha, 2003.

[7] ČSN EN ISO 6508-1, (2006): Kovové materiály - Zkouška tvrdosti podle Rockwella - Část1: Zkušební metoda (stupnice A, B, C, D, E, F, G, H, K, N, T). Praha, 2006.

[8] DIN EN 1071-6 (2008): Advanced technical ceramics - Methods of test for ceramic coatings - Part. 6: determination of the abrasion resistance of coatings by a micro-abrasion wear test;.German version EN 1071-6:2007. 2008.

[9] ČSN EN ISO 4287, (1999): Geometrické požadavky na výrobky (GPS) - Struktura povrchu: Profilová metoda - Termíny, definice a parametry struktury povrchu. Praha, 1999.

[10] ČSN EN ISO 25178-2, (2012): Geometrické specifikace produktu (GPS) - Textura povrchu: Plocha - Část 2: Termíny, definice a parametry textury povrchu. Praha, 2012.

[11] ČSN EN ISO 13565-2, (1999): Geometrické požadavky na výrobky (GPS) - Struktura povrchu: Profilová metoda - Povrchy mající stratifikované vlastnosti - Část 2: Výškové charakteristiky využívající křivky lineárního materiálového poměru. Praha, 1999.

[12] Handbook Talysurf CCI - Lite Non-contact 3D Profiler, 2008 